\title{
Cryptococcal cerebrospinal fluid shunt infection treated with fluconazole
}

\author{
Daniel EYMARD, MD, FrançoIs LeBEL, MD
}

\begin{abstract}
D EyMard, F LEBel. Crytopcoccal cerebrospinal fluid shunt infection treated with fluconazole. Can J Infect Dis 1993;4(4):227-228. A 37-year-old woman with a cadaveric renal allotransplantation required intra-cranial shunting devices after a presumptive episode of tuberculous meningitis. Six months later, she developed a culture-proven cryptococcal meningitis. Without having her ventriculo-auricular shunt removed, she was successfully treated with a short course of amphotericin B (335 mg) and flucytosine (nine days) followed by prolonged therapy with oral fluconazole (400 mg daily for 72 days). Three years post treatment she had no evidence of relapse, and normal renal graft function.
\end{abstract}

Key Words: Cryptococcus neoformans, Fluconazole, Renal transplant, Shunt infection

\section{Cryptococcose au niveau du liquide céphalo-rachidien suite à un shunt, traitée par fluconazole}

RÉSUMÉ: Une femme de 37 ans ayant subi une allotransplantation rénale a requis l'implantation d'un dispositif de shunt intracrânien après un épisode soupçonné de méningite tuberculeuse. Six mois plus tard, elle a développé une méningite à Cryptococcus confirmé par les résultats de culture. Sans que l'on ait eu à extraire le shunt ventriculo-auriculaire, elle a êté traitêe avec succès grâce à l'administration d'amphotéricine B (335 mg) durant une brève période et de flucytosine (durant neuf jours), suivie d'un traitement prolongé avec fluconazole par voie orale (400 mg par jour durant 72 jours). Trois ans après le traitement, elle ne présentait aucun signe de rechute et la fonction de la greffe rênale était normale.

$\mathrm{C}$ JRRENT STANDARD THERAPY FOR CRYPTOCOCCAL MENINgitis is amphotericin $\mathrm{B}$, either alone or in combination with flucytosine (1). Treatment with amphotericin B is, however, problematic in clinical scenarios where preservation of renal function is an urgent priority. In renal transplant recipients, although this regimen is effective (2), it may threaten the viability of the renal graft (3). In theory, therefore, fluconazole suggests itself as a favourable alternative to amphotericin $\mathrm{B}$ in renal transplant patients who require treatment of cryptococcal meningitis. We report clinical success in a renal transplant patient treated with fluconazole for cryptococcal meningitis.

\section{CASE PRESENTATION}

A 37-year-old woman with Alport's syndrome underwent a cadaveric renal allotransplantation in 1973 and again in 1985. Four months prior to the 1985 graft, therapy with isoniazid and rifampin was initiated for a presumptive diagnosis of tuberculous meningitis. Cerebrospinal fluid (CSF) analysis revealed pleocytosis with a white cell count of $0.035 \times 10^{9} / \mathrm{L}$ and a red cell count of $0.015 \times 10^{9} / \mathrm{L}$, elevated protein at $1.2 \mathrm{~g} / \mathrm{L}$, and low glucose CSF-to-serum ratio of 0.07. CSF bacterial, fungal, mycobacterial and viral cultures were all negative. Cryptococcal antigen detection (Crypto-La test, International Biologic Labs, New Jer-

Department of Microbiology and Medicine, Montreal General Hospital, McGill University, Montreal, Quebec

Correspondence and reprints: Dr Daniel Eymard, Centre hospitalier Pierre-Boucher, 1333 Jacques Cartier est, Longueuil,

Québec J4M 2A5. Telephone (514) 468-8111, Fax (514) 468-8240

Received for publication December 20, 1991. Accepted July 14, 1992 
sey) was negative on CSF and serum. Three additional weekly CSF examinations failed to yield any pathogen. The patient's clinical course remained uneventful for the next three years.

The patient's medical condition deteriorated in February of 1988 when a symptomatic hydrocephalus required surgical decompression via a ventriculoperitoneal shunt. From May onwards, there were three consecutive monthly episodes of distal shunt obstruction. Following the last episode, the shunt was replaced by a ventriculo-auricular shunt. On each occasion, bacterial culture of peritoneal fluid and shunt tubing were negative.

One month following the replacement of the shunt, the patient was admitted after $24 \mathrm{~h}$ of fever $\left(39.6^{\circ} \mathrm{C}\right)$, chills, headache, and vertigo. She was taking cyclosporine, prednisone, phenytoin, and rifampin. Chest $\mathrm{x}$-ray revealed an area of consolidation in the left lower lobe. The CSF values were: white cell count $0.015 \times 10^{9} / \mathrm{L}$; red cell count $0.072 \times 10^{9} / \mathrm{L}$; protein 0.27 $\mathrm{g} / \mathrm{L}$; and glucose CSF-to-serum ratio 0.53. India ink and mucicarmine CSF stains showed encapsulated yeast-like organisms, and Cryptococcus neoformans was isolated and identified using API 20C (Analytab products, New York). CSF cryptococcal antigen detection was negative at dilutions of $1: 1,1: 10$ and 1:100. Bacterial and mycobacterial cultures of CSF were negative. Treatment was initiated with amphotericin B, flucytosine (discontinued on day 9 because of myelosuppression), and cefotaxime. Immunosuppressive therapy was left unchanged apart from withholding the cyclosporine for the first five days of therapy. The patient's clinical condition rapidly improved on this treatment regimen. In order to avoid nephrotoxicity, amphotericin B was replaced on day 19 (total dose 335 $\mathrm{mg}$ ) with fluconazole (400 mg daily) for a further 72 days, with no adverse effect. Although CSF fungal cultures had been negative on day 16 and day 22 , recurrence of symptomatic hydrocephalus led to revision of the patient's ventriculo-auricular shunt one month after introduction of fluconazole. CSF cultures

ACKNOWLEDGEMENTS: The authors thank Dr Howard Dawang for reviewing this manuscript

\section{REFERENCES}

1. Bennett JE, Dismukes WE, Duma RJ, et al. A comparison of amphotericin B alone and combined with flucytosine in the treatment of cryptococcal meningitis. N Engl J Med 1979;301:126-31.

2. Watson AJ, Russell RP, Cabreja RF, Braverman R, Whelton A. Cure of cryptococcal infection during continued immunosuppressive therapy. Q J Med 1985:217:169-72

3. Kennedy MS, Deeg HJ, Siegel M, Crowley JJ, Storb R, Thomas ED. Acute renal toxicity with combined use of amphotericin B and cyclosporin after marrow transplantation. Transplantation 1983:35:211-5.

4. Wu TC, Koo SY. Comparison of three commercial cryptococcal latex kits for detection of cryptococcal antigen. J Clin Microbiol 1983:18:1127-30. were negative at that time and the hydrocephalus improved postoperatively. Three years post treatment the patient is doing well, with no evidence of relapse, and normal renal graft function.

\section{DISCUSSION}

Cryptococcal antigen could not be demonstrated in the patient's CSF, even though the kit used has previously been shown to be both highly sensitive and specific (4). A false negative result secondary to a prozone effect was excluded by performing the test at various dilutions. Other investigators have explained similar false negative results by positing a low production of antigen in their isolates (5). In one published series, antigen was not detected in eight of 88 acquired immune deficiency syndrome (AIDS) patients with proven cryptococcal meningitis (6).

Although the present patient received a 19-day course of amphotericin B, it cannot account for her clinical cure. In another published series (7), four of five renal transplant patients with cryptococcal meningitis relapsed after a short course of 28 days of amphotericin B. Therefore, although the amphotericin B and flucytosine may have decreased the burden of cryptococci, the durability of her long term cure must be ascribed to the fluconazole.

Fluconazole already has a well-established clinical role in the treatment of AIDS patients, both as definitive treatment of cryptococcal meningitis in patients at low risk for treatment failure (8), as well as for long term suppression of cryptococcal disease in this population (9). Fluconazole has also been reported to induce a cure in a renal transplant patient with cryptococcal meningitis (10). This is the first report of fluconazole treatment for a fungal CSF shunt infection in an immunocompromised host. Sequential treatment with an initial short course of amphotericin B and flucytosine followed by prolonged fluconazole is an effective regimen for cryptococcal meningitis in patients at high risk for amphotericin-related nephrotoxicity.

5. Haldane DJ, Bauman DS, Chow AW, et al. False negative latex agglutination test in cryptococcal meningitis. Ann Neurol 1986;19:412-3. (Letter)

6. Chuck SL, Sande MA. Infections with Cryptococcus neoformans in the acquired immunodeficiency syndrome. $\mathrm{N}$ Engl $\mathrm{J}$ Med 1989;321:794-9.

7. Dismukes WE, Cloud G, Gallis HA, et al. Treatment of cryptococcal meningitis with combination amphotericin B and flucytosine for four as compared with six weeks. N Engl J Med 1987;317:334-41

8. Saag MS, Powderly WG, Cloud GA, et al. Comparison of amphotericin B with fluconazole in the treatment of acute AIDS-associated cryptococcal meningitis. N Engl J Med 1992:326:83-9.

9. Sugar AM, Saunders C. Oral fluconazole as suppressive therapy of disseminated cryptococcosis in patients with acquired immunodeficiency syndrome. Am J Med 1988;85:481-9.

10. Conti DJ, Tolkoff-Rubin NE, Baker GP, et al. Successful treatment of invasive fungal infection with fluconazole in organ transplant recipients. Transplantation 1989;48:692-5. 


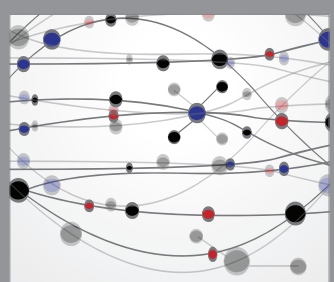

The Scientific World Journal
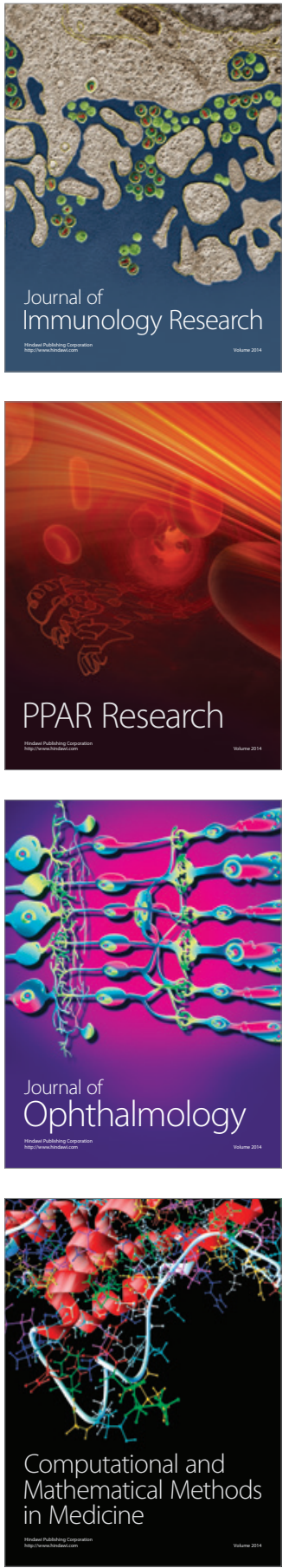

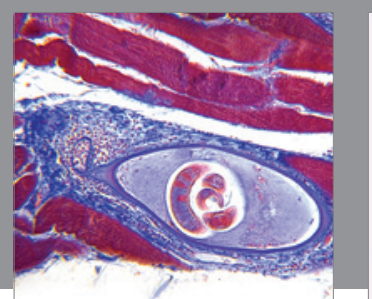

Gastroenterology Research and Practice

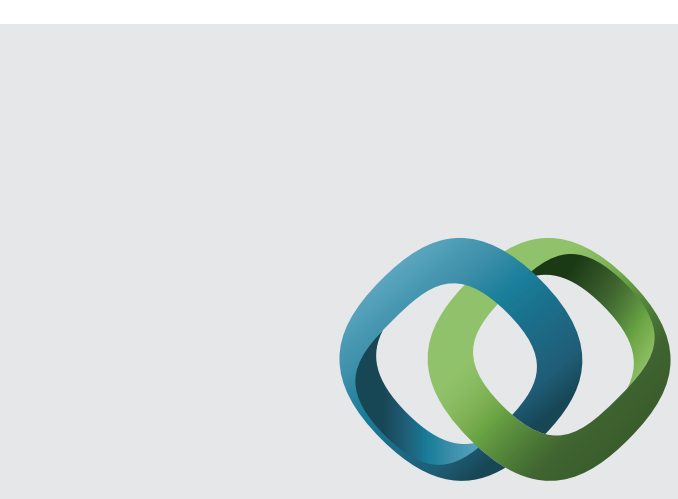

\section{Hindawi}

Submit your manuscripts at

http://www.hindawi.com
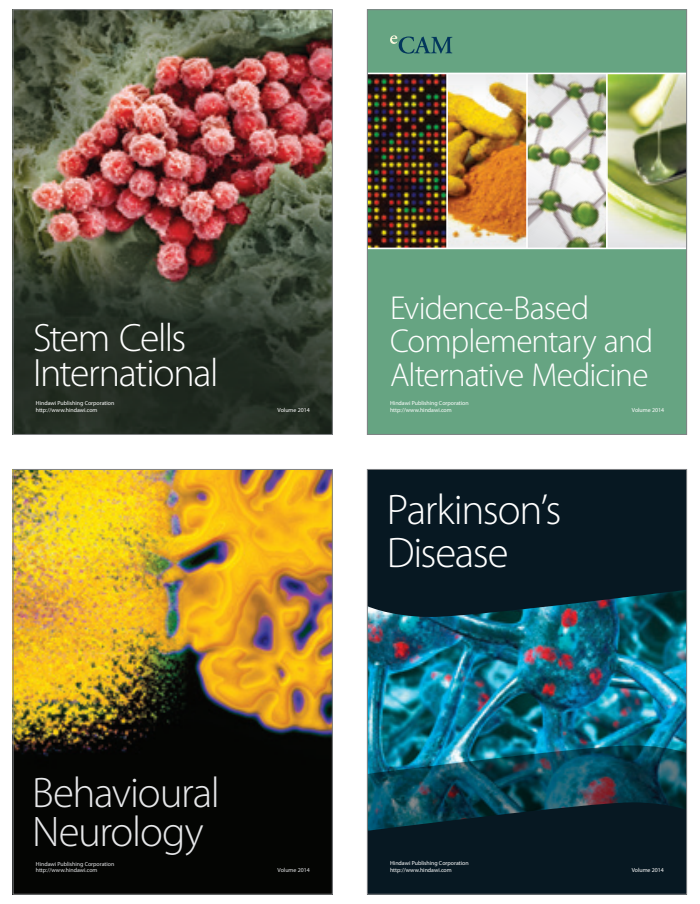
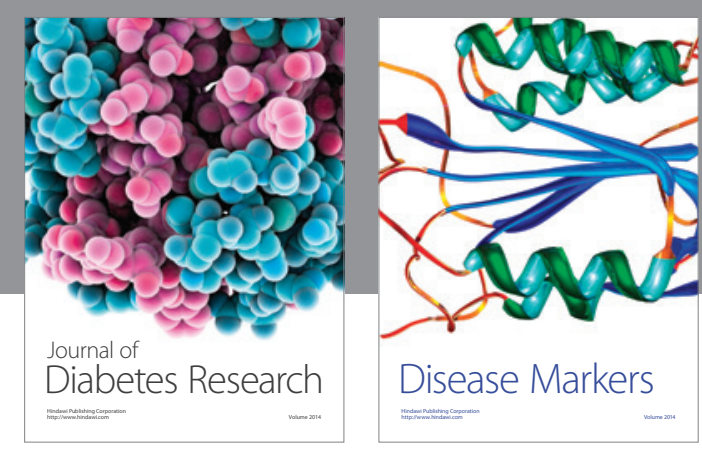

Disease Markers
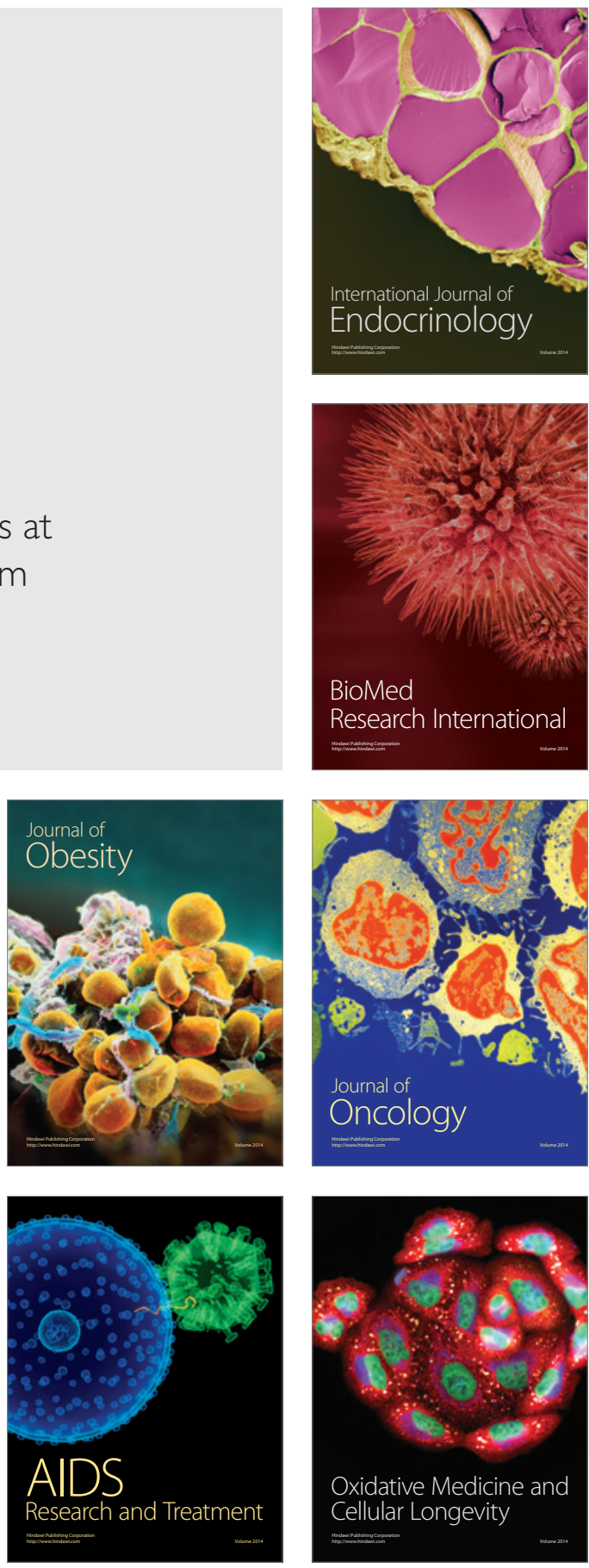